\title{
PERBEDAAN TINGKAT PARTIPASI SEBAGAI AKSEPTOR KELUARGA BERENCANA BERDASARKAN STATUS SOSIAL EKONOMI KELUARGA
}

\author{
Rafika Nur Camelia 1), Guspri Devi A ${ }^{2)}$, Shinta Doriza ${ }^{3)}$ \\ shintadoriza75@gmail.com \\ 1,3) Program Studi Pendidikan Kesejahteraan Keluarga
2) Program Studi Tata Boga \\ Fakultas Teknik, Universitas Negeri Jakarta
}

\begin{abstract}
Abstrak
Penelitian ini bertujuan untuk mengetahui perbedaan tingkat partisipasi sebagai akseptor KB berdasarkan status sosial ekonomi keluarga di Kantor Badan Kependudukan dan Keluarga Berencana Nasional Pusat. Penelitian ini dilakukan selama 6 bulan sejak bulan Januari sampai dengan Juni 2015. Metode penelitian yang digunakan adalah metode kuantitatif dengan pendekatan survey. Populasi pada penelitian ini adalah PNS di BKKBN Pusat yang sudah menikah dan telah memiliki anak. Teknik pengambilan sampel yang digunakan adalah Simple random sampling. Sampel berjumlah 128 responden. Tingkat partisipasi sebagai akseptor KB dilihat berdasarkan status sosial ekonomi keluarga. Hasil pengujian hipotesis statistik menggunakan Anova satu arah didapatkan Fhitung $=20,84$ pada taraf kesalahan 0,05 sehingga dapat disimpulkan bahwa terdapat perbedaan tingkat partisipasi sebagai akseptor KB berdasarkan status sosial ekonomi keluarga menengah atas dan status menengah bawah. Hasil penelitian menunjukkan bahwa tingkat partisipasi sebagai akseptor KB dapat dilihat berdasarkan status sosial ekonomi keluarga. Tingkat partisipasi sebagai akseptor KB berdasarkan status sosial ekonomi keluarga menengah atas lebih tinggi dibandingkan status sosial ekonomi keluarga menengah bawah. Alat kontrasepsi yang banyak digunakan adalah IUD.
\end{abstract}

Kata kunci: Tingkat Partisipasi, Status Sosial Ekonomi Keluarga.

\section{THE DIFFERENCE IN PARTICIPATION RATES AS ACCEPTORS KB BASED ON FAMILY SOCIO-ECONOMIC STATUS}

\begin{abstract}
This research aims to know the difference in participation rates as acceptors $\mathrm{KB}$ based on socio-economic status families in an Office of BKKBN. This research was conducted for 6 months from January until June 2015. The research method used was survey approach with quantitative methods. The population in this research is the public employee at the Centre of BKKBN married and have had children with 128 samples. The level of participation as acceptors KB views based on socio-economic status families. The results of statistical hypothesis testing using one-way Anova $F=20.84$ count obtained on the extent of error 0.05 so it can be inferred that there is a difference in the level of participation as acceptors based on socio-economic status KB family of high and middlelower status. The results showed that the level of participation as acceptors KB can be seen based on socio-economic status families. The level of participation as acceptors KB based on socio-economic status families are higher than those of high socioeconomic status of families under the medium. Contraception is widely used is the IUD.
\end{abstract}

Keywords: Participation Rates, Socio-Economic Status Families. 


\section{PENDAHULUAN}

Status sosial ekonomi keluarga merupakan suatu kedudukan yang dihasilkan dari pendapatan yang diperlukan untuk memenuhi kebutuhan keluarga. Suatu kedudukan yang dimiliki keluarga terbagi atas dua bagian, yaitu keluarga dengan status sosial ekonomi kelas atas dan keluarga dengan status sosial ekonomi kelas bawah.

Keluarga dengan status sosial ekonomi kelas atas merupakan keluarga yang memiliki kemampuan lebih untuk memenuhi semuakebutuhan keluarga, pendapatan keluarga yang cukup dapat memenuhi semua kebutuhan anggota keluarga. Sedangkan keluarga dengan status sosial ekonomi kelas bawah cenderung kurang dapat memenuhi semua kebutuhan keluarganya.

Keluarga dengan status sosial ekonomi kelas atas memiliki kemampuan yang lebih baik, dikarenakan kebutuhan keluarga yang dapat terpenuhi dengan baik. Dalam hal ini status sosial ekonomi kelas atas menunjukkan bahwa tingkat partisipasi dalam program KB tinggi dikarenakan keluarga dengan status sosial ekonomi kelas atas biasanya memiliki kesibukan sendiri dan tidak ingin memiliki anak dengan jumlah banyak. Walaupun dengan ekonomi yang cukup baik keluarga dengan status ekonomi atas lebih banyak yang memiliki jumlah anak yang sedikit atau sesuai dengan program KB.

Sedangkan pada keluarga dengan status sosial ekonomi kelas bawah menunjukkan tingkat partisipasi dalam program KB rendah , ditambah denan presepsi banyak anak banyak rejeki, biasanya keluarga dengan status sosial ekonomi kelas bawah memiliki jumlah anak yang banyak. Mereka kurang memikirkan untuk membatasi jumlah anak padahal dengan jumlah anak yang banyak maka pemenuhan kebutuhan anggota keluarga meningkat.

Persepsi ini berbeda dengan hasil penelitian Margono (1997; 147-154), dengan judul "Pengaruh Tingkat Sosial Ekonomi dan Sikap Buruh Terhadap Program Keluarga Berencana". Menunjukkan bahwa masyarakat kelas sosial ekonomi tinggi umumnya lebih kritis daripada kelas sosial ekonomi rendah dan lebih banyak diantaranya kurang setuju dengan program Keluarga Berencana pemerintah. Setelah diteliti terdapat hasil dari hipotesis tersebut yakni kelas sosial ekonomi tinggi hanya sebagian kecil yang setuju dengan program KB pemerintah yakni 20\% (Zuriah, 2013: 151-152).

Keluarga dengan status sosial ekonomi kelas atas pada kenyataannya memiliki tingkat partisipasi yang tinggi, dengan memiliki jumlah anak sesuai program KB. Berdasarkan tingkat partisipasi sebagai akseptor KB berarti keluarga dengan status sosial ekononi kelas atas memiliki kesadaran akan ber-KB.

Berdasarkan data di atas maka penulis ingin mengetahui bagaimana perbedaan tingkat partisipasi sebagai akseptor KB berdasarkan status sosial ekonomi keluarga. Pada penelitian ini akan dilihat tingkat partisipasi dalam program Keluarga Berencana pada Pegawai Negeri Sipil. Data yang diperoleh dari Badan kepegawaian BKBBN, jumlah Pegawai Negeri Sipil di BKKBN Pusat per Januari 2015 berjumlah 680 orang.

Pegawai Negeri Sipil di BKKBN, merupakan pembuat dan pelaksana untuk mencapai keberhasilan program Keluarga Berencana. Penulis ingin mengetahui Pegawai Negeri Sipil yang Ber-KB, namun data yang telah diperoleh dari klinik BKKBN pada pegawai negeri sipil yang ikut ber-KB, tidak menunjukkan hasil yang signifikan.

\section{METODE PENELITIAN}

Metode yang digunakan dalam penelitian ini adalah metode penelitian kuantitatif. Penelitian ini menggunakan pendekatan survei karena dianggap paling tepat untuk mengumpulkan data (Arikunto, 2010: 3). Populasi dan sampel dalam penelitian ini yaitu seluruh Pegawai Negeri Sipil wanita yang bekerja di kantor BKKBN yang sudah menikah dan telah memiliki anak. Populasi dalam penelitian ini berjumlah 188 orang, sedangkan sampel dalam penelitian ini berjumlah 128 orang dengan penentuan jumlah sampel menggunakan rumus Slavin.

Teknik sampling yang digunakan dalam penelitian ini dengan cara Simple random sampling merupakan pengambilan sampel yang dilakukan secara acak (Hariwijaya, 2004; 47). Variabel dalam penelitian ini terdapat satu variabel, yaitu tingkat partisipasi sebagai akseptor KB berdasarkan status sosial ekonomi keluarga.

Definisi operasional dalam penelitian ini yaitu status sosial ekonomi keluarga dan 
tingkat partisipasi sebagai akseptor KB. Status sosial ekonomi keluarga adalah status seseorang atau keluarga dalam masyarakat yang mencakup indikator 1) jenis pekerjaan, 2) sumber pendapatan, 3) kategori tempat tinggal dan 4) area tempat tinggal, dan memodifikasi jenis pekerjaan dilihat dari jabatan Pegawai Negeri Sipil, yang diukur dengan pemberian skor sesuai skor ISC status sosial ekonomi.

Partisipasi keluarga dalam program KB adalah keterlibatan sukarela keluarga yang merupakan unit terkecil dalam masyarakat yang ikut terlibat sebagai akseptor KB dalam suatu usaha merencanakan jumlah dan jarak anak yang diinginkan, yang diukur melalui pengisian angket yang mencakup indikator 1) pengambilan keputusan, 2) pelaksanaan, 3) evaluasi, dengan kriteria penilaian sangat setuju (SS), setuju (S), tidak setuju (TS), dan sangat tidak setuju (STS).

Untuk pengujian hipotesis digunakan untuk membandingkan besarnya variabel yang dibagi atau dibedakan menjadi lebih dari dua kategori. Jika ada perbedaan, rata-rata manakah yang lebih tinggi dengan menggunakan ANOVA satu arah dengan taraf signifikansi 0,05. Selanjutnya, dilanjutkan dengan menggunakan uji schfee untuk mengetahui signifikasi data hasil penelitian, dengan hipotesis yang diajukan.

\section{HASIL DAN PEMBAHASAN}

Sesuai dengan latar belakang masalah yaitu bagaimana tingkat partisipasi sebagai akseptor KB berdasarkan status sosial ekonomi keluarga, maka ditegakkan hipotesis dalam penelitian ini adalah terdapat perbedaan tingkat partisipasi sebagai Akseptor KB berdasarkan status sosial ekonomi keluarga.

Berdasarkan perhitungan Uji ANOVA satu arah, hasil menunjukkan terdapat perbedaan tingkat partisipasi sebagai akseptor KB berdasarkan status sosial menengah atas dan status sosial menengah bawah. Tingkat partisipasi sebagai akseptor KB jika dilihat dari rata-rata maka status sosial ekonomi menengah atas memiliki nilai tertinggi yaitu 111,32 dengan jumlah responden 78 orang, sedangkan nilai terendah terdapat pada tingkat partisipasi berdasarkan status sosial menengah bawah yaitu dengan rata-rata 103,72 dengan jumlah responden 50 orang.

Hasil penelitian ini menunjukkan status ekonomi mempengaruhi tingkat partisipasi sebagai akseptor KB, status sosial ekonomi menengah atas menunjukkan tingkat partisipasi yang lebih tinggi daripada status sosial ekonomi menengah bawah. Dan terdapat perbedaan tingkat partisipasi sebagai akseptor KB berdasarkan status sosial ekonomi menengah atas dan status sosial ekonomi menengah bawah.

\section{KESIMPULAN}

Hasil penelitian ini menunjukkan status ekonomi mempengaruhi tingkat partisipasi sebagai akseptor KB, status sosial ekonomi menengah atas menunjukkan tingkat partisipasi yang lebih tinggi daripada status sosial ekonomi menengah bawah. Dan terdapat perbedaan tingkat partisipasi sebagai akseptor KB berdasarkan status sosial ekonomi menengah atas dan status sosial ekonomi menengah bawah.

$$
\text { Berdasarkan hasil penelitian }
$$
secara keseluruhan tingkat partisipasi sebagai akseptor KB berdasarkan status ekonomi keluarga menengah atas memiliki presentase tertinggi dibandingkan status ekonomi keluarga menengah bawah.

Hasil perhitungan dengan ANOVA satu arah didapatkan Fhitung sebesar 20,84 sedangkan Ftabel dengan taraf kesalahan 0,05 nilai pembilang 1 dan penyebut 126 diperoleh sebesar 3,92. Dalam hal ini berlaku ketentuan bahwa bila Fhitung < Ftabel maka $\mathrm{H}_{0}$ diterima sedangkan $\mathrm{Ha}_{\mathrm{a}}$ ditolak dan Fhitung > Ftabel maka $\mathrm{H}_{0}$ ditolak sedangkan $\mathrm{H}_{\mathrm{a}}$ diterima. Dengan demikian, $\mathrm{H}_{0}$ ditolak dan $\mathrm{H}_{a}$ diterima. Artinya, terdapat perbedaan tingkat partisipasi sebagai akseptor KB berdasarkan status sosial ekonomi keluarga menengah atas dan status menengah bawah.

\section{DAFTAR PUSTAKA}

Adi, Rianto. $2004 . \quad$ Metodelogi Penelitian Sosial dan Hukum. Jakarta: Rahmatika Creative Design.

Arikunto, S. 2010. Prosedur Penelitian Suatu Pendek atan. Jakarta: Rineka Cipta.

Astuti, Siti. I. $2010 . \quad$ Desentralisasi dan Partisipasi Masyarak at dalam Pendidik an: 


\section{Pustaka Pelajar.}

Azhari, lbnu. K. 2011. Tingk at partisipasi masyarak at pada tahap perencanaan dalam program Neighbouhood Development. Surakarta: Universitas Sebelas Maret.

Hariwijaya dan Djaelani . 2008. Teknik Skripsi dan Tesis. Yogyakarta: [penerbit tidak diketahui].

Kartono. 2006. Perilaku Manusia. Jakarta: PT. Rajagrafindo Persada.

Kusnadi, Hendar. 2009. Ekonomi Koperasi:

Depok: Lembaga Penerbit UI.

Riduwan. 2009. Belajar Mudah Penelitian untuk Guru- Karyawan dan Peneliti Pemula. Bandung: Alfabeta.

Slamet, Y. Pembangunan Masyarak at Berwawasan Partisipasi.Surakarta: Sebelas Maret University Press.

Slavin, R.E. 2000. Educational Phycilogy Theory and Prestise. Sixth Edition Boston: Allyn and Bacon.

Sugiyono. 2013. Metode Penelitian Kombinasi (mixed methods). Bandung: Alfabeta.

Zuriah, Nurul. 2006. Metodelogi Penelitian Sosial dan Pendidikan. Jakarta: Bumi Aksara. 